\title{
A Review of Recent Advances in Ultrasound, Placed in the Context of Pain Diagnosis and Treatment
}

\author{
Michael S. Bobola ${ }^{1} \cdot$ Lucas Chen $^{1} \cdot$ Chikodinaka K. Ezeokeke $^{1} \cdot$ Katy Kuznetsova ${ }^{2}$ - Annamarie C. Lahti ${ }^{1}$. \\ Weicheng Lou ${ }^{1} \cdot$ Aleksey N. Myroniv ${ }^{1}$ • Nels W. Schimek ${ }^{1}$ • Madison L. Selby ${ }^{1}$ • Pierre D. Mourad ${ }^{1,2,3}$
}

Published online: 10 July 2018

(C) The Author(s) 2018

\begin{abstract}
Ultrasound plays a significant role in the diagnosis and treatment of pain, with significant literature reaching back many years, especially with regard to diagnostic ultrasound and its use for guiding needle-based delivery of drugs. Advances in ultrasound over at least the last decade have opened up new areas of inquiry and potential clinical efficacy in the context of pain diagnosis and treatment. Here we offer an overview of the recent literature associated with ultrasound and pain in order to highlight some promising frontiers at the intersection of these two subjects. We focus first on peripheral application of ultrasound, for which there is a relatively rich, though still young, literature. We then move to central application of ultrasound, for which there is little literature but much promise.
\end{abstract}

Keywords Ultrasound $\cdot$ Peripheral nerve stimulation $\cdot$ Pain diagnosis $\cdot$ Pain $\cdot$ Pain treatment

\section{Ultrasound for Peripheral Nerve Stimulation}

In the early 1970s, researchers used both focused and unfocused ultrasound to evoke tactile sensation in human subjects. Gavrilov and colleagues investigated the use of stimulatory ultrasound to induce tactile, thermal, and painful sensations in the human hand [1-4]. For example, in Gavrilov 1977a, the authors studied the sensations generated by ultrasound delivered to the skin or below the skin as a function of intensity and water temperature. The piezoceramic transducers delivered ultrasound at resonant frequencies of $0.48,0.887$, and $2.67 \mathrm{MHz}$, and maximum intensities of 1300,8000 , and $30,000 \mathrm{~W} / \mathrm{cm}^{2}$. Both the subject's hand and the ultrasound transducer were submerged in warm bath water at temperatures of 30,35 , or $40^{\circ} \mathrm{C}$. Each subject described the presence

This article is part of the Topical Collection on Neuromodulation

Pierre D. Mourad

doumitt@uw.edu

1 Department of Neurological Surgery, University of Washington, Seattle, WA, USA

2 Applied Physics Laboratory, University of Washington, Seattle, WA, USA

3 Division of Engineering and Mathematics, University of Washington, Bothell, WA, USA or absence of sensation during ultrasound application to either their skin or the deep tissues for a duration of $1 \mathrm{~ms}$, followed by 10 and $100 \mathrm{~ms}$. Stimulation stopped immediately after the test subjects reported pain associated with ultrasound application. At lowest intensity values of ultrasound - the "threshold intensity"- - test subjects felt a tactile sensation, described by them as a "local touch," a "slightly sensed stroke," or a "slight push." Interestingly, the threshold intensity for induction of a tactile sensation increased as the frequency of ultrasound increased. Also, the threshold intensity increased with movement of the focal region within the skin layer from the fingers to forearm. At larger intensity values, the sensation felt by subjects involved modification of temperature sensing. Specifically, in a way that varied between test subjects, ultrasound applied directly to the skin induced sensations of warmth and cold, sensations that disappeared when ultrasound of the same intensity focused below the skin layer. As was the case for tactile sensations, threshold intensity values for ultrasound-induced temperature sensations increased as its delivery point moved from the finger to the forearm. Moreover, depending on water temperature, stimulation of a given sensitive spot generally created a cold sensation $\left(\right.$ at $30{ }^{\circ} \mathrm{C}$ ) or warm sensation $\left(\right.$ at $40^{\circ} \mathrm{C}$ ). As a means of studying the biophysical processes that lay behind these observations, the authors calculated the particle velocity, sound pressure, displacement, and temperature of tissue induced by ultrasound and 
correlated those calculations with the observed threshold intensity values. All those physical parameters other than tissue displacement increased as a function of intensity. Only the displacement amplitude of tissue within the focal volume of ultrasound application at its threshold value was independent of frequency [1]. Therefore, biophysical process of a mechanical nature plays a significant role, at least, in the stimulation of peripheral tissue.

Others, motivated by Gavrilov and colleagues, have explored many of the concepts implicit or explicit in their work. For example, one of the main goals of the work led by Dalecki [5] was to test the hypothesis that the tactile sensation experienced through direct exposure of tissue to ultrasound is caused by that tissue's exposure to the acoustic radiation force, itself related to the absorption by tissue of ultrasound. Experiments used an acoustically reflecting target, Corprene, set on the tissue site. This cork/rubber compound contained large amounts of trapped air so that it acted as an acoustic reflector. That reflection resulted in displacement of the Corprene, hence displacement of the underlying tissue. Importantly, the Corprene prevented the direct exposure of tissue to ultrasound yet produced local displacement of tissue without the induction of cavitation and of heat within tissue. Thresholds for tactile perception during ultrasound exposure of a portion of forearm away from bone with the Corprene target were compared to those of direct exposure of the forearm. They used ultrasound with a carrier frequency of $2.2 \mathrm{MHz}$ and considered four pulse durations: 5,10, 50, and $100 \mathrm{~ms}$. Across their protocol, the observed ultrasound threshold intensity values for perception of ultrasound did not depend upon the absence or presence of Corprene. This result supports the investigators' hypothesis that ultrasound-induced tactile sensations arise due to the acoustic radiation force. In addition, Dickey et al. [6] also determined threshold values for perceived sensations, using pulses of ultrasound that lasted for $0.1 \mathrm{~s}$, delivering actual or sham ultrasound at a carrier frequency of $2 \mathrm{MHz}$ into the fingertip pads of healthy test subjects. They observed an increase in sensitivity to ultrasound delivery as a function of increased intensity values. Of note, this increase in sensitivity to ultrasound stimulation correlated inversely with the density of peripheral nerve terminals in the fingertip pads, itself determined through use of a two-point discrimination test, consistent with the hypothesis of Gavrilov (1984) [3].

The work reviewed above used intense focused ultrasound (iFU) - ultrasound with intensities above FDA limits for diagnostic ultrasound) which has dealt with stimulating healthy tissue, in vivo and in humans. Of note, Gavrilov (1984) [3] hypothesized that clinicians could 1 day use iFU application to distinguish between healthy and neuropathic tissue, based on the qualities of the sensations evoked by ultrasound stimulation, thereby providing a noninvasive method for focally locating neural abnormalities in patients. Motivated by that hypothesis, researchers have shown it possible to elicit diagnostically relevant responses using inflammatory rat models of pain [7-9], neuropathic rat models of pain [10, $11]$, and patients $[12,13]$. In all these papers, the authors found a lower intensity of ultrasound was required to elicit a discernible sensation or withdrawal response after application of iFU to damaged tissue than when applied to control (healthy) tissue.

For example, McClintic et al. [8] set out to show that iFU stimulation could be used as a noninvasive, targeted test for identifying inflamed tissue. A 0.375 -s pulse of 2-MHz ultrasound was applied in a randomized fashion to the hind paws of rats, one of which was inflamed; the other, not. They observed that after application of iFU, the inflamed paw withdrew at a lower threshold of ultrasound intensity $100 \%$ of the time, and that iFU threshold values were two times higher for normal paws than for inflamed paws, a statistically significant result. An acute safety study [9] found that 20 separate $0.1-\mathrm{s}$ iFU applications at $1000 \mathrm{~W} / \mathrm{cm}^{2}$ spaced $10 \mathrm{~s}$ apart produced no observable cell damage in rats in the subcutaneous area of ultrasound application, while 30 0.1-s iFU applications at $2000 \mathrm{~W} / \mathrm{cm}^{2}$ did produce observable damage in four rats. Interestingly, Garcia et al. (2014) [7] used the same rat model of inflammation to observe a significant diurnal difference in iFU threshold values, with high specificity and sensitivity. Specifically, the thresholds for stimulation for both single pulse and multiple pulse protocols were significantly higher at night than during the day, consistent with the diurnal pattern of pain for rodents, and lending hope to the idea that iFU stimulation could track pain management through time.

Motivated by these in vivo results for inflammatory tissue, these same researchers have used image-guided iFU (ig-iFU) to study peripheral pain generators in humans with known inflammatory pain in their shoulder. Specifically, Gelhorn, Gillenwater, and Mourad (2015) [12] applied ig-iFU to candidate trouble spots in the shoulders of patients with rotary cuff tendinosis. They used a Sonosite ultrasound imaging device, coupled with a $2.0-\mathrm{MHz}$ iFU transducer to deliver iFU in individual pulses of length $0.1 \mathrm{~s}$ with escalating intensity values until either the test subject gave definitive reports of sensation induction or the iFU device reached its maximum intensity value. These researchers identified the iFU intensity threshold values of sensation induction in rotary cuff tendons along with several other sites in each group of participants, with values significantly less than that observed for control subjects. It was determined that while neither the healthy volunteers nor osteoarthritis patients reported any sensation upon application of iFU, patients with rotary cuff tendinosis did report reliable sensation induction in their rotary cuff tendon and surrounding tissue at a spatial and temporal average intensity $\left(I_{\text {SATA }}\right)$ value of $680 \pm 281 \mathrm{~W} / \mathrm{cm}^{2}$.

Regarding neuropathic pain, Tych et al. (2013) [10] and McClintic et al. (2013) [11] sought to demonstrate that iFU could distinguish between diffuse neuropathic tissue and 
healthy tissue. Tych et al. (2013) used an ultrasound pulse of $1.15-\mathrm{MHz}$ frequency, applied for $0.2 \mathrm{~s}$ into the hind paws of rats, one distal to pSNL (partial sciatic nerve ligation), the other left alone. Then, the rats were observed for instantaneous paw withdrawal. If there was no withdrawal, the intensity of the ultrasound was increased in $30 \%$ increments starting at $50 \mathrm{~W} / \mathrm{cm}^{2}$ until two consecutive single paw withdrawals were observed, defining this intensity as the iFU threshold. Tych et al. (2013) observed in pSNL rats that the rat withdrew its ipsilateral $98 \%$ of the time in 59 trials without withdrawing its contralateral paw at the same iFU intensity value. An average intensity and dose of $176 \pm 56 \mathrm{~W} / \mathrm{cm}^{2}$ and $37.4 \pm 11(\mathrm{~W} /$ $\left.\mathrm{cm}^{2}\right) *_{\mathrm{s}}$ was required to see a response in pSNL. The intensity and dose of ultrasound required to elicit a response in the sham surgery rats was $217 \pm 25 \mathrm{~W} / \mathrm{cm}^{2}$ and $43.4 \pm 5\left(\mathrm{~W} / \mathrm{cm}^{2}\right)^{*} \mathrm{~s}$, respectively, while in the control rats, the ultrasound device could not elicit a response even at its maximum intensity and dose of $283 \mathrm{~W} / \mathrm{cm}^{2}$ and $56.6\left(\mathrm{~W} / \mathrm{cm}^{2}\right)^{*} \mathrm{~s}$, respectively. This study demonstrates that diffuse neuropathic tissue is more sensitive to iFU compared to healthy tissue.

McClintic et al. (2013) [11] sought to extend this work to focal and subcutaneous neuropathic tissue, specifically a neuroma. The authors applied a single, 2-MHz ultrasound pulse that lasted for $0.1 \mathrm{~s}$ to the neuroma while the rat was under light anesthesia. (They located the neuroma through anatomical markers and verified its sensitivity through use of von Frey hairs.) For control tissue, they stimulated an area of the rat's leg $1 \mathrm{~cm}$ away from the neuroma towards the body. Starting at low intensity values, McClintic increased the iFU intensity in 10-30\% increments targeting the neuroma until they observed three reliable flicks of its ipsilateral paw. After this observation, the authors applied the same intensity of iFU to the control area to see if it would elicit a response. In 21 out of 25 tests, the iFU elicited a response after application to the neuroma but not after its application to the control area. The results of this study agree with the results found by Tych et al. (2013) that neuropathic tissue is more sensitive than healthy tissue to iFU stimulation. These results further support the hypothesis that iFU stimulation can help differentiate painful tissue (here, subcutaneous neuropathic tissue) from normal tissue.

Motivated by McClintic et al. (2013) [11], Mourad et al. (2017) [13] used this same concept of ig-iFU stimulation to assay in a preliminary way the peripheral pain generators within the residual limbs of amputee patients. The researchers had access to five 2-MHz image-guided intense focused ultrasound transducers, each with a different depth of focus (specifically, $0.4,1.3,2.45,2.75$, and $3.0 \mathrm{~cm}$ ) to target the transected nerve within the residual limbs of both standard amputee patients and those who had undergone a targeted nerve innervation (TNI) procedure. They applied $0.1 \mathrm{~s}$ of iFU stimulation to both the severed nerve endings and the immediately proximal section of the same nerve. When time permitted, they also applied iFU to the corresponding contralateral and intact nerve. They increased the applied intensity from $16 \mathrm{~W} / \mathrm{cm}^{2}$ until a reliable intensity threshold for sensation induction was found, or else stopped at $1032 \mathrm{~W} / \mathrm{cm}^{2}$, the maximum value of intensity achieved by the device. One or two neuromas were identified using ultrasound imaging for each of the four TNI patients. For three out of four TNI patients, they found an iFU threshold stimulation value below the maximum value produced by the transducer. For all three of those successful stimulation cases, the proximal nerve had the same iFU intensity value as for the neuroma itself. For the standard amputation group, neuromas were identified in three of the seven patients. For two of these three patients, the intensity threshold was the same in the neuroma and proximal nerve, while for the third patient, iFU applied to the proximal nerve did not generate a sensation, while for the distal neuroma, it did. For the remaining four out of seven standard amputees, iFU applied to the transected nerve end also generated a discernable sensation. Of particular interest, most successful iFU stimulation tests produced phantom limb sensations; also, for only one of the 11 test subjects could the authors elicit a discernable sensation with iFU applied to the contralateral and intact nerve, and then not in a reproducible fashion. Finally, the iFU threshold values trended inversely but were not statistically significant for phantom limb pain and pain associated with the participants' residual limb in the standard amputee patients while both had a statistical inverse correlation in the TNI group.

Wright and colleagues [14] conducted a study that tested the ability of rapidly repeated application of focused ultrasound to induce temporal summation within skin, muscles, and joints. The stimulations occurred in single or sets of four pulses applied across a range of application frequency and duration with a center frequency of $1.66 \mathrm{MHz}$. They found a lower threshold for observable sensation induction when they rapidly applied multiple pulses than when they applied a single pulse, consistent with the idea that ultrasound could induce temporal summation. Expanding on this, McClintic and colleagues [8] used a rat model of chronic inflammation to compare the threshold for immediate paw withdrawal through a single burst of focused ultrasound and a series of rapidly applied bursts. They used a transducer with a center frequency of $2 \mathrm{MHz}$ and a range of $I_{\text {SATA }}$ intensity values between 100 and $1622 \mathrm{~W} / \mathrm{cm}^{2}$ and found that five rapidly applied 75-ms iFU pulses spaced $75 \mathrm{~ms}$ apart produced withdrawal of the inflamed rat paw at lower iFU intensity values than a single 75-ms burst, consistent with the presence of temporal summation in this chronic pain model and the results of Wright and colleagues. However, the total acoustic dose and predicted heat increase were the same in the single burst and multiple burst protocols which produced paw withdrawal. This suggests that while temporal summation may allow for sensation induction at a lower iFU intensity in the multiple pulse 
condition through rapid pushing of this sensitive tissue, a temperature increase alone or in addition may have generated paw withdrawal behavior in these animals (Table 1).

\section{Ultrasound Alone for Anesthesia and Analgesia}

As noted in the introduction, there exists a rich history of the use of diagnostic ultrasound imaging to facilitate delivery of drugs that temporarily block the function of peripheral nerves in order to generate regional anesthesia. Interestingly, evidence exists pointing to the possibility that more intense ultrasound than that capable of producing a sensation, applied directly to a peripheral nerve, can transiently and safely reduce that nerve's function. Because ultrasound is noninvasive, utilizing focused ultrasound to reversibly block nerve conduction for analgesia and anesthesia therefore has considerable appeal.

Colucci et al. 2009 [15] applied ultrasound to the sciatic nerve of bullfrogs. They tried two different ultrasound frequencies (0.661 and $1.986 \mathrm{MHz}$ ) and two different pulse durations (1 and $10 \mathrm{~ms}$ ) and two different application rates (10 and 20 times per second), for $30 \mathrm{~s}$ in duration. Ultrasound stimulation significantly reduced up to $60 \%$ of the nerves' action potential, which returned to baseline several minutes after ultrasound application. A thermacouple placed inside of the nerve recorded focal heat generated by the ultrasound, with that heat increase correlated with the observed action potential reduction. This work therefore not only demonstrated transient decrease in nerve function after application of focused ultrasound but also pointed towards at least one mechanism by which ultrasound created this effect.

Hong et al. 1991 [16] showed that focused ultrasound could reversibly block nerve conduction in humans. They applied, transcutaneously, 1-min physio-therapeutic ultrasound at a frequency of $2 \mathrm{MHz}$ to the peroneal nerve of healthy test subjects at intensities of $0.5,1.0$, and $1.5 \mathrm{~W} /$ $\mathrm{cm}^{2}$. This stimulation produced a significant reduction in compound muscle action potential (CMAP), with a $41.4 \%$ decrease at $1.0 \mathrm{~W} / \mathrm{cm}^{2}$ and $44 \%$ decrease at $1.5 \mathrm{~W} / \mathrm{cm}^{2}$, but not at $0.5 \mathrm{~W} / \mathrm{cm}^{2}$. Normal CMAP production returned to baseline $5 \mathrm{~min}$ after ultrasound stimulation.

Going beyond transient reduction of nerve function, Foley and colleagues demonstrated that much higher intensity ultrasound applied to a major nerve could stop nerve function through induction of distal axon degeneration. Specifically, Foley et al. [17] monitored the motor function of the hind limbs of twelve rabbits following application of high-intensity focused ultrasound, intra-operatively, to the rabbit's sciatic nerves. (They assayed motor function intra-operatively as well, through placement of a stimulating electrode proximal to the point of high-intensity focused ultrasound (HIFU) application and observation of paw movement in response to electrical stimulation.) They used HIFU with a spatial and temporal average intensity of $1930 \mathrm{~W} / \mathrm{cm}^{2}$ delivered at $3.2 \mathrm{MHz}$, in 5-s intervals, until electrical stimulation could not induce a motor response. They observed a lack of motor response (assayed intra-operatively as above) for up to 14 days after HIFU application, consistent with associated histological examination, which showed distal axon degeneration (Table 2).

Table 1 Summaries of representative articles in section "Ultrasound for Peripheral Nerve Stimulation"

\begin{tabular}{|c|c|c|c|}
\hline Article & Model & US parameters & Result/conclusion \\
\hline Tych et al. (2013) [10] & $\begin{array}{l}\text { In vivo partial sciatic nerve } \\
\text { ligation }(\mathrm{pSNL}) \text { in } \\
\text { Sprague-Dawley rats }\end{array}$ & $\begin{array}{l}\text { 1.15-MHz pulses } \\
0.2 \mathrm{~s} \\
\text { Responses at: } \\
\text { pSNL: } 176 \pm 56 \mathrm{~W} / \mathrm{cm}^{2} I_{\text {SATA }} \\
\text { sham: } 217 \pm 25 \mathrm{~W} / \mathrm{cm}^{2} I_{\text {SATA }} \\
\text { normal: greater than } 283 \\
\quad \mathrm{~W} / \mathrm{cm}^{2} I_{\text {SATA }}\end{array}$ & $\begin{array}{l}\text { Neuropathic tissue is more sensitive to } \\
\text { stimulation by intense focused ultrasound } \\
\text { (iFU) than control tissue. }\end{array}$ \\
\hline McClintic et al. (2013) [11] & $\begin{array}{l}\text { In vivo neuroma in paw of } \\
\text { Sprague-Dawley rats }\end{array}$ & $\begin{array}{l}\text { 2-MHz pulses } \\
0.1 \mathrm{~s} \\
\text { Response at: } \\
\text { Mechanical: } 5.7 \pm 2.2 \mathrm{~g} \\
\text { iFU: } 343 \pm 77 \mathrm{~W} / \mathrm{cm}^{2}\end{array}$ & $\begin{array}{l}\text { Successful stimulation of the neuroma by } \\
\text { intense focused ultrasound required } \\
\text { co-localization of the neuroma and intense } \\
\text { focused ultrasound }\end{array}$ \\
\hline Wright et al. (2002) [14] & $\begin{array}{l}\text { Distal interphalangeal joint of index } \\
\text { finger of human }\end{array}$ & $\begin{array}{l}\text { Experiment } 1 \\
4 \text { pulses at } 2 \mathrm{~Hz} \\
25 \mathrm{~ms} \\
50 \mathrm{~ms} \\
75 \mathrm{~ms} \\
100 \mathrm{~ms} \\
\text { Experiment } 2 \\
0.5 \mathrm{~Hz}, 1 \mathrm{~Hz}, 2 \mathrm{~Hz}, 3 \mathrm{~Hz} \text {, } \\
\quad 4 \mathrm{~Hz}, 5 \mathrm{~Hz} \\
\text { Constant pulse of } 50 \mathrm{~ms}\end{array}$ & $\begin{array}{l}\text { Experiment 1: } \\
\text { "...a progressive decrease in pain thresholds } \\
\text { was found with increased stimulus duration" } \\
\text { Experiment 2: } \\
\text { "Analysis of variance showed a significant } \\
\text { interaction between tissue stimulated and } \\
\text { pulse-train frequency." }\end{array}$ \\
\hline
\end{tabular}


Table 2 Summaries of representative articles in section "Ultrasound Alone for Anesthesia and Analgesia"

\begin{tabular}{|c|c|c|c|}
\hline Article & Model & US Parameters & Result/conclusion \\
\hline Colucci et al. (2009) [15] & $\begin{array}{l}\text { In vivo, bullfrog, } \\
\text { sciatic nerve }\end{array}$ & $\begin{array}{l}0.661 \mathrm{MHz} \\
1.986 \mathrm{MHz} \\
1 \mathrm{~ms}, 10 \mathrm{~ms} \text { for } 10 \text { and } \\
20 \text { pulses per second, for } 30 \mathrm{~s}\end{array}$ & $\begin{array}{l}\text { "Thermal mechanism of focused } \\
\text { ultrasound can be used to block } \\
\text { nerve conduction, either temporarily } \\
\text { or permanently." }\end{array}$ \\
\hline Hong et al. (1991) [16] & $\begin{array}{l}\text { In vivo, human, } \\
\text { peroneal nerve }\end{array}$ & At $0.5 \mathrm{~W} / \mathrm{cm}^{2}, 1.0 \mathrm{~W} / \mathrm{cm}^{2}, 1.5 \mathrm{~W} / \mathrm{cm}^{2}$ & $\begin{array}{l}\text { "Ultrasonic therapy with therapeutic } \\
\text { dosage may cause a reversible conduction } \\
\text { block on patients with painful } \\
\text { polyneuropathy." }\end{array}$ \\
\hline Foley et al. (2006) [17] & $\begin{array}{l}\text { In vivo, rabbit, } \\
\text { sciatic nerve }\end{array}$ & $\begin{array}{l}1930 \mathrm{~W} / \mathrm{cm}^{2} \\
3.2 \mathrm{MHz} \\
\text { 5-s intervals }\end{array}$ & $\begin{array}{l}\text { Conduction nerve block of all } 12 \text { sciatic } \\
\text { nerves was achieved with average HIFU } \\
\text { treatment time of } 10.5 \pm 4.9 \mathrm{~s} \text { (mean } \pm \mathrm{SD}) \text {. }\end{array}$ \\
\hline
\end{tabular}

\section{High-Intensity Focused Ultrasound to Treat Peripheral Sources of Pain}

Though ultrasound, as a means of imaging, can guide RF ablation [18], ultrasound of a different sort-HIFU—of sufficient intensity can permanently destroy tissue. Here we first review MRI-guided HIFU systems, known as MRgHIFU, that represent a highly precise means of delivering HIFU. We then move on to their peripheral and central applications to pain treatment.

\section{MRgHIFU Systems for Delivering High-Intensity Focused Ultrasound}

The first applications of MRI-guided high-intensity focused ultrasound began in the 1990s, with feasibility studies done on tissues to assess the thermal effects of focused ultrasound for the use of minimally invasive surgery.

Important early work showed the usefulness of MRI guidance for HIFU. In 1992, Jolesz and Hynynen al. [19] treated an acoustic silicone phantom gel and a bovine muscle with high-intensity focused ultrasound using MR imaging guidance. The experiments were done with a 1.1- and a $1.5-\mathrm{MHz}$ transducer. With the 1.1-MHz transducer, the real-time MR imaging was able to show physical changes in the phantom gel and the bovine muscle at the site of the focus, as well as provide a temperature reading throughout the procedure. The procedures were done at various power levels and real-time MR imaging allowed for observation of HIFU-induced temperature increases from 30 to $60{ }^{\circ} \mathrm{C}$. The study found reversible effects of HIFU with temperatures below $60^{\circ} \mathrm{C}$, with nonreversible effects above that temperature.

In 1993, Hynynen et al [20] also studied the feasibility of HIFU application under MRI guidance, as well as the feasibility of detecting tissue necrosis induced by HIFU with MR imaging, all in real time. For their experiments, Hynynen et al. used six, co-focused 1.1-MHz ultrasound transducers, each made of MRI-compatible materials, and a GE Signa 1.5T
MR imaging system for the experiments, with the transducers placed within the MR bore. The experiments sonicated greyhounds' thigh muscle while monitoring the tissue temperature rise and structural changes via MR imaging. The study found that sonications of $20 \mathrm{~s}$ or longer produced visible (by MR) lesions in tissue. Lesions were immediately detected and the magnitude of the change (of lesions) correlated with the duration of the sonication. Postmortem analysis of the tissue found that the size and shape of lesions correlated with the MR images. The study showed that MR systems can be used to monitor HIFU therapy as well as give real-time feedback on the dimension and location of targeted volumes.

\section{Advantages of MRI Guidance Over Ultrasound Guidance}

MR imaging is more advantageous than ultrasound imaging [21] for guidance of therapy using HIFU because MRI provides more information. MR imaging provides highresolution anatomical imaging as well as thermal mapping with uninterrupted feedback during therapy [20]. Thermal mapping of the tissue is done directly from MR images, providing information about the thermal diffusion within the tissue, which ultimately defines the length of the HIFU therapy $[20,22]$. Unlike other imaging methods, MR imaging provides excellent resolution of soft tissues, such as brain, joints, and spine. MRI guidance also allows for imaging from different planes (axial, sagittal, coronal, and oblique) without repositioning the subject. This is very important and beneficial during therapy for optimal targeting and monitoring of surrounding tissues. In instances of transcranial focused ultrasound surgery (FUS) therapy, MR imaging provides realtime feedback of location of focus of the transducer within the brain.

This is all in contrast to ultrasound imaging, with its lower resolution, significant operator dependency, and limited view of the tissue of interest. Moreover, diagnostic ultrasound does not currently have the ability to effectively monitor temperature [21]. 


\section{Systems Available from Manufacturers}

Currently, there are four MRIgHIFU systems available: the Sonalleve, the TULSA-PRO, the ExAblate O.R., and the ExAblate Neuro. The first three target the periphery while the fourth specializes in the brain.

The Sonalleve system was developed by Phillips to treat uterine fibroids and palliative pain of bone metastases. Philips sold the system to Profound Medical in June, 2017. The Sonalleve system includes an MR system with HIFU transducer built for noninvasive ablation. The HIFU transducer system includes a water cooling system to keep the patient's skin temperature constant, and the system is embedded into the MR table. The MR system provides 3D images for planning and real-time feedback of tissue temperature during HIFU therapy [23].

Profound Medical has an additional MRIgFU system, TULSA-PRO, for the treatment of prostate cancer and ablation of prostate tumors. The system incorporates a robotic therapeutic ultrasound transducer that provides ablation of prostate tumors. The MR system provides real-time feedback of temperature of the target volume as well as the surrounding tissues. The system also provides tissue cooling through the rectum and urethra for the protection of tissues surrounding the volume target [24].

Another MRIgHIFU system that was developed for treatment of uterine fibrosis and palliative pain of bone metastases is the ExAblate O.R., created through a collaboration between GE and Insightec. This system includes an MR system and a table-embedded HIFU transducer for ablation therapy. Similar to other systems, the MR system provides 3D images for therapy planning and tissue temperature monitoring during therapy.

\section{Ablation of Peripheral Tissue by Ultrasound to Ameliorate Bone Pain Due to Cancer}

Several researchers have explored tissue ablation with HIFU to treat pain, especially bone pain [25]. In all cases, they used MRI-guided high-intensity focused ultrasound. Osteoid osteoma, for example, is a type of bone cancer that produces significant pain often along the cortical long bones. Current conservative treatments include aspirin, also known as acetylsalicylic acid (ASA) or nonsteroidal anti-inflammatory drugs (NSAIDs). Surgical interventions include surgical en bloc resection or curettage. The success of surgery for reducing or removing the cancer pain $(88-100 \%)$ comes with the price of increased complication rates $(35 \%)$ relative to conservative treatment [26]. HIFU introduces a noninvasive alternative to surgical treatment of this pain, one that may spare adjacent anatomical structures [26].

Hurwitz et al. [27] tested the ability of HIFU ablation of painful, generally metastasized cancer to reduce that pain.
Here, patients with metastatic growths emanating from cancers such as breast, kidney, lung, and prostate were evaluated prior to treatment using MRI to determine the size and locations of the area designated for HIFU treatment. Pain levels were also recorded using a numerical scale to quantify pain experienced by the patient [28]. After establishing those baseline values, patients underwent 2-4-h (including $83 \pm 43 \mathrm{~min}$ for sonication) MRI-guided focused ultrasound treatment and were evaluated for pain in the treated tissue using the Numeric Rating Scale (NRS) and the Brief Pain Inventory (BPI-QoL). The results of their study conveyed a statistical significance ( $p$ $<0.05)$ in both measures when patients receiving the ablation treatment were compared to the sham cohort. Although there were 51 reported adverse events in the cohort $(n=112)$ that received focused ultrasound, more than half of them were resolved on the day they arose.

Napoli et al. (2017) [29] found similar results in a clinical trial: a decrease in pain after application of HIFU therapy to painful but benign bone tumors. They studied 29 patients who were diagnosed with osteoid osteoma and treated with MRgFUS therapy. Twenty-seven of the 29 patients reported an absence of pain without consuming any analgesics following the treatment. Their recorded pain score on the visual analog scale (VAS) significantly decreased from a 7.9 baseline to a score of 0.7 up to 24 months after treatment [28]. Encouragingly, they did not observe any complications associated with the treatment. These results support using HIFU as a precise and minimally invasive method to ablate, hence treat pain caused by bone cancer. Similarly, Li et al. (2010) [30] conducted a study on patients with malignant bone tumors. They observed HIFU therapy to successfully ablate the tumor such that the patients experienced a reduction in their pain. In this study, 25 patients with malignant bone tumors received HIFU treatment. Of the 25 patients, 24 of them experienced pain from their bone tumors before treatment. In order to measure the pain experienced, Li et al. (2010) used a verbal scale from 0 to 3 to rate pain: 0 indicating no pain, 1 indicating mild pain, 2 indicating moderate pain, and 3 indicating severe pain. The pain scores in the patients decreased from $1.84 \pm 0.85$ before HIFU therapy to $0.12 \pm 0.33$ after HIFU therapy. In the 24 patients experiencing pain, 21 of them $(87.5 \%)$ were completely relieved of pain.

Yarmolenko PS et al. [31] and Sharma et al. [32] also explored the feasibility and safety of using MRI-guided HIFU to ablate osteoid osteoma. Nine patients under the age of 25 , resistant to medical treatment, with lesions targetable with MR-HIFU were selected to participate in this study. Five days prior to treatment, both patient groups of MR-HIFU had evaluations of VAS recorded. For MR-HIFU patients, they were put under general anesthesia with a Sonalleve V2 HIFU system paired with an Achieva 1.5T MR scanner. Temperature scans of low-power sonications sufficient to induce a temporary rise in tissue temperature without causing ablation were 
applied prior to actual HIFU ablation to guide the HIFU treatment. Procedure time lasted, on average, $128 \mathrm{~min}$ with varying acoustic power and sonication duration dependent upon variables such as overlying bone thickness and osteoid osteoma characteristic.

The patients were interviewed several times (at 1, 7, 14, and 28 days post-treatment) to determine their VAS pain score and pain medication use. Patient median VAS score decreased from an average value of 6 down to $0(P=0.0002)$. Moreover, after treatment, eight out of nine patients stopped using NSAID. Finally, the patients experienced statistically significant increase in their sleep quality after HIFU treatment.

Taken together, these results and others' [33-35] point to the ability of high-intensity focused ultrasound, under MRI guidance, to ablate boney lesions in a way that reduced their associated pain (Table 3).

\section{(Towards) Use of Focused Ultrasound Applied to the Brain to Treat Pain}

The skull represents a considerable barrier to ultrasound propagation into the brain, the major problem for those seeking to use focused ultrasound to treat portions of the brain associated with the experience of pain. Ultrasound not only attenuates in amplitude through absorption by the bone but also reflects and scatters the incident ultrasound as well as converts it from pressure to shear waves. These factors, as well as the variable thickness of the skull throughout its circumference, including inter-patient variability, while in play for diagnostic ultrasound, pose a quite significant problem for intense ultrasound, which puts the skull at risk for significant heating [36]. Current approaches alter the phase of the incident ultrasound based upon either CT scan-based mathematical modeling of ultrasound propagation or measurements of brain-tissue displacement caused by low levels of the acoustic radiation force [37]. In this way, intentional and designed initial defocusing of the ultrasound external to the skull yields a focused beam of ultrasound within the brain.

As mentioned above, GE and Insight created the ExAblate O.R., with its table-embedded HIFU transducer for ablation therapy. To treat brain, they modified this system to create the ExAblate Neuro, an MRIgHIFU system built to deliver HIFU across the skull. The system includes a novel HIFU system that incorporates one of the ultrasound focusing paradigms just discussed. It also has a helmet to help cool the patient's head. Specifically, it includes a water cooling system that keeps the patient's skin and skull cool, while the transducer's $650 \mathrm{kHz}, 1024$-element phased array provides precise targeting and treatment of the selected volume [38].

Thanks to the ability of MR to detect small changes in temperature, users of the ExAblate Neuro can refine the position of the ultrasound focus via measurement of the location of a sub-ablation thermal spot induced by HIFU. Once the clinicians have confirmation of the desired location of the HIFU focus, they then increase the acoustic power in a stepwise fashion until the tissue reaches the therapeutic target temperature $\left(52-59^{\circ} \mathrm{C}\right)$. To ensure the safety of patients, sonication temperatures are monitored throughout the procedure with MR thermometry while the patients are fully responsive, awake, and questioned repeatedly to avoid adverse effects.

\section{Ablation of the Brain to Treat Pain}

The ExAblate Neuro system has had its most extensive tests applied to the treatment of essential tremor due to Parkinson's disease (PD), with one application to pain treatment. Since MRgHIFU treatment of essential tremor (ET) and pain each require ablation of brain tissue, we include essential tremor here to provide to the readers a sense of the range of HIFU

Table 3 Summaries of representative articles in sections "MRgHIFU Systems for Delivering High-Intensity Focused Ultrasound" and "Ablation of Peripheral Tissue by Ultrasound to Ameliorate Bone Pain Due To Cancer"

\begin{tabular}{|c|c|c|c|}
\hline Article & Model & US parameters & Result/conclusion \\
\hline Liberman et al. 2009 [33] & In vivo, bone metastases & $\begin{array}{l}\text { - Avg. time: } 66 \mathrm{~min} \\
\quad \text { (range } 22-162 \mathrm{~min} \text { ) } \\
\text { - Avg. sonications: } 17.3 \\
\quad \text { (range } 8-32 \text { ) }\end{array}$ & $\begin{array}{l}\text { - VAS score reduction } \\
\text { - Edema at target area } \\
\text { - No lasting damage, } \\
\text { some calcification of target area }\end{array}$ \\
\hline Hurwitz et al. 2016 [27] & In vivo, bone metastases & $\begin{array}{l}\text { - Avg. sonication time: } 83 \pm 43 \mathrm{~min} \\
\text { - Max } 65-85^{\circ} \mathrm{C}\end{array}$ & - NRS score reduction, $p<0.001$ \\
\hline Napoli et al. 2017 [29] & $\begin{array}{l}\text { In vivo, human } \\
\text { Osteoid osteomas }\end{array}$ & $-4 \pm 1.8$ sonications & $\begin{array}{l}\text { - VAS score reduction } \\
(p=0.001) \\
\text { - } 27 / 29 \text { patients had pain absence } \\
\text { and no intake of NSAIDs }\end{array}$ \\
\hline Li et a. $2010[30]$ & $\begin{array}{l}\text { In vivo, human } \\
\text { Osteosarcoma, malignant } \\
\text { fibrous histiocytoma }\end{array}$ & $\begin{array}{l}\text { - } 70 \text { to } 169 \mathrm{~W} / \mathrm{cm}^{2} \\
\text { - Scanning speed }=1-3 \mathrm{~mm} / \mathrm{s} \\
\text { - Avg. sessions }=2.29 \mathrm{~h}\end{array}$ & $\begin{array}{l}\text { - Pain reduction of } p<0.05 \\
\text { - PET-CT revealed no abnormal } \\
\text { radioactivity concentration in } \\
\text { tumor areas. }\end{array}$ \\
\hline
\end{tabular}


parameters necessary to ablate brain tissue associated with pain.

Chang et al. [39] studied the efficacy of using unilateral magnetic resonance-guided ultrasound thalamotomy for essential tremor treatment. Following treatment, patients were assessed on tremor severity and functional impairment using a critical scale for tremor (CRST [40]). Follow-ups occurred at 1 week, 1 month, 3 months, and 6 months after treatment. Eight out of the 11 patients that could be considered for analysis showed significant improvement in parts A, B, and C of the CRST.

Magara et al. [41] demonstrated that the use of MRgFUS can provide similar improvements to these patients compared to radiofrequency pallidothalamic tractotomy. Thirteen patients (range 37 to 82 years) with therapy-resistant PD were approved for MRgFUS treatment, divided into two cohorts. Group 1 (patients 1-4) received a single application of peak temperature while group 2 (patients 5-13) received applications of peak temperature four to five times. After treatments, follow-ups were held at 2 days and 3 months. At the 3-month follow-up post-treatment, group 1 showed a mean UPDRS (unified Parkinson's disease rating scale [42]) reduction of $7.6 \%$ while group 2 showed a mean reduction of $60.9 \%$.

Chang et al. [39] observed comparable results in a prospective study of eleven patients' essential tremor, 8/11 of which received sufficient HIFU to ablate tissue, and all experiencing immediate reduction in tremor-related symptoms out to 6 months - the end of the study period. Interestingly and in contrast to some other studies, the MRI manifestation of the HIFU lesions disappeared 3 months after HIFU application. Chazen et al. [43] observed similar clinical results for MRgFUS treatment of essential tremors as well as demonstrated the ability of diffusion tensor imaging to target ablation sites for MRgFUS. Post-operative imaging of their four patients showed a lesion at the desired location and physician evaluation demonstrated a significant improvement of symptoms.

For patients with chronic and therapy-resistant neuropathic pain, there are few options to reduce their pain. In response to this, a team in Switzerland [44] recruited nine patients (aged 45 to 75 ) for a selective central lateral thalamotomy. Before treatment with MRgHIFU began, they confirmed the location of the HIFU focus with low sonications with 10 to 20 -s durations applied to temperatures of 39 to $42^{\circ} \mathrm{C}$, below the threshold for ablation, but are visible on the MR thermometry to confirm an accurate focus point. After achieving confirmation, the authors gradually increased the HIFU power in order to achieve peak temperature of $53-60{ }^{\circ} \mathrm{C}$ with continuous wave sonication at individual durations of 10 to $20 \mathrm{~s}$. During the procedure, patients experienced a variety of effects such as temporary pain relief, vestibular feelings, and dysesthesias. The treatment created lesions of 3 to $5 \mathrm{~mm}$ in length, with pain relief ranged from 30 to $100 \%$ relative to their baseline scores. In addition, they did not observe any adverse effects. These preliminary findings indicate that MRgHIFU could be a safe and reliably precise noninvasive option for neurosurgery interventions [44].

Three years later, Jeanmonod et al. [45] achieved similar results with central lateral thalamotomy, which they performed on 12 patients with chronic therapy-resistant neuropathic pain. Prior to treatment, they applied several low-power sonications of 10 to $20 \mathrm{~s}$, achieving MRI-detected temperatures of 39 to $42{ }^{\circ} \mathrm{C}$, thereby confirming the location of the focus relative to the anatomical target. After this step, they began therapy, continuing until they observed a temperature range of $51-64{ }^{\circ} \mathrm{C}$ at the HIFU focus. The mean VAS score of the preoperative patients was 59.5/100 with "significant" relief in pain $($ mean $=55 \%)$ after the procedure. Post-operative follow-ups occurred with patients at the end of the procedure, 2 days, 3 months, and 1 year. In all instances of follow-up, the VAS score was significantly decreased relative to baseline, with a mean score of $35.3 / 100$ on year post-operation. In addition, five out of eight patients from the study did not use drugs to combat pain at the 1-year mark, while all did before treatment (Table 4).

\section{Towards Modulating Brain Function with Ultrasound to Treat Pain}

In this section, we discuss observations that show that ultrasound can activate or deactivate the brain in a temporary and non-destructive fashion. As surely this audience knows, pain is a personal experience that requires brain function. Therefore - and speaking speculatively at this point - deactivation of relevant brain regions by ultrasound, or activation of a portion of the brain that inhibits downstream brain function, could have direct application to reducing a person's experience of pain. In anticipation of future studies that explore these possibilities, we review here recent observations of ultrasound's temporary effect on brain function.

Ultrasound-facilitated modulation of brain function (UNMOD) has experienced a resurgence since the early work in the 1950s performed by the Fry brothers [46] who, for example, observed that ultrasound delivered to the visual cortex of anesthetized cats could temporary deactivate it for $30 \mathrm{~min}$. Leading this resurgence, Tyler and colleagues [47] directly measured neuron activation by ultrasound through placement of an electrode within the hippocampus of a slice of mouse brain, itself within the field of largely unfocused ultrasound at delivered at $500 \mathrm{kHz}$. Next, through the use of transcranial pulsed ultrasound that encompassed the majority of mouse brain, they induced generally bilateral peripheral motor activity such as tail and paw flicks and whisker movements [48]. King et al. [49] and Ye, Brown, and Pauly [50] produced comparable behavioral results, including with a wider exploration of neuromodulatory frequency. Younan et 
Table 4 Summaries of representative articles in section "Ablation of the Brain to Treat Pain"

\begin{tabular}{|c|c|c|c|}
\hline Article & Model & US parameters & Result/conclusion \\
\hline Magara et al. 2012 [41] & $\begin{array}{l}\text { In vivo, human } \\
\text { Pallidothalamic tract }\end{array}$ & $\begin{array}{l}710 \mathrm{kHz} \\
\text { Mean application time: } \\
13 \mathrm{~s}(\text { range } 10-21) \\
\text { Peak temp: } \\
52-59^{\circ} \mathrm{C}\end{array}$ & $\begin{array}{l}\text { Group 1: avg. lesion of } 83 \mathrm{~mm}^{3} \\
\text { with disappearance at } 3 \text { months } \\
\text { Group 2: avg. lesion of } 172 \mathrm{~mm}^{3} \\
\text { with maintained visualization } \\
\text { at } 3 \text { months }\end{array}$ \\
\hline Chazen et al. 2017 [43] & $\begin{array}{l}\text { In vivo, human } \\
\text { Thalamotomy }\end{array}$ & $\begin{array}{l}650 \mathrm{kHz} \\
\text { mean application time: } 10-20 \mathrm{~s} \\
\text { Peak temp: } \\
55-62{ }^{\circ} \mathrm{C}\end{array}$ & $\begin{array}{l}\text { Reduction in contralateral intention } \\
\text { tremor }\end{array}$ \\
\hline Chang et al. 2014 [39] & $\begin{array}{l}\text { In vivo, human } \\
\text { Thalamotomy }\end{array}$ & $\begin{array}{l}650 \mathrm{kHz} \\
\text { Mean application time: } 10-20 \mathrm{~s} \\
\text { Peak temp: } \\
55-62{ }^{\circ} \mathrm{C}\end{array}$ & $\begin{array}{l}\text { Immediate and sustained improvements } \\
\text { in tremors } \\
\text { Lesion of thalamic nucleus }\end{array}$ \\
\hline Martin et al. 2009 [44] & $\begin{array}{l}\text { In vivo, human } \\
\text { Central lateral thalamotomy (CLT) }\end{array}$ & $\begin{array}{l}650 \mathrm{kHz} \\
\text { Mean application time: } 10-20 \mathrm{~s} \\
\text { Peak temp: } \\
53-60{ }^{\circ} \mathrm{C}\end{array}$ & $\begin{array}{l}3-5 \text {-mm lesion in } 48 \text {-h post-op MRI } \\
\text { Long-term }(\sim 3.75 \text { years) pain relief } \\
\text { between } 50 \text { and } 100 \% \text { in } 53 \% \text { of patients }\end{array}$ \\
\hline Jeanmonod et al. 2012 [45] & $\begin{array}{l}\text { In vivo, human } \\
\text { Central lateral thalamotomy (CLT) }\end{array}$ & $\begin{array}{l}650 \mathrm{kHz} \\
\text { Mean application time: } 10-20 \mathrm{~s} \\
\text { Peak temp: } \\
51-64{ }^{\circ} \mathrm{C}\end{array}$ & $\begin{array}{l}\text { Lesions of } 3-4 \mathrm{~mm}(\mathrm{~d}) \\
\text { Mean post-op VAS score reduction of } 42.3 \text { and } \\
40.7 \% \text { at } 3 \text { months and } 1 \text { year respectively }\end{array}$ \\
\hline
\end{tabular}

al. [51] produced similar observations coupled with a detailed numerical study of the ultrasound patterns within rodent brain. Moore et al. [52] demonstrated that ultrasound-induced EEG signals have temporal structure consistent with known activity in pyramidal neurons, as shown by comparison with their observed optogenetic stimulation.

To further increase the anatomical specificity of UNMOD, Tufail and colleagues [48] used an ultrasound collimator to produce directly measured action potentials generated within one hemisphere of the intact mouse brain. Yoo et al. [53] used a pulsed, $690-\mathrm{kHz}$ focused ultrasound protocol on anesthetized rabbits, showing via functional magnetic resonance imaging (fMRI), electromyography (EMG), and gross observation that ultrasound delivered to one side of the brain induced observable brain function on the contralateral side, with focal volumes smaller than a hemisphere of brain. For their second study [54], the authors used a $350-\mathrm{kHz}$ focused ultrasound protocol to stimulate at least a cranial nerve associated with control of an eye of an anesthetized rat, with motion induced ipsilateral to the stimulation zone. Kim et al. [55] showed with PET imaging that, among several results, the focal volume of the brain activated by $500-\mathrm{kHz}$ ultrasound measures much smaller (given by a contour defined by the $90 \%$ of the peak value of pressure in the focus) than the focal volume of ultrasound defined physically (given by a contour defined by $50 \%$ of the peak value of pressure). This same group demonstrated in a rat model significant reduction of visually evoked potentials after application of ultrasound with one set of parameters (focused ultrasound with a $350-\mathrm{kHz}$ carrier frequency, pulse repetition frequency of $100 \mathrm{~Hz}$, spatial-peak pulse-average acoustic intensity of $3 \mathrm{~W} / \mathrm{cm}^{2}$ ), with a slight enhancement of visually evoked potentials after application of ultrasound with slightly greater intensity and dose. They were motivated by earlier work [53] that demonstrated, in rabbits, UNMOD's ability to reduce brain activity generated by light exposure and monitored by functional magnetic resonance imaging.

Mehic et al. [56] further demonstrated increased anatomical specificity of ultrasound stimulation of rodent brain, including large variations in motor response caused by small, lateral displacements of the ultrasound target — on the order of a millimeter. Kamimura et al. [57] achieved similar results as well as observed transient eye movement induced by ultrasound. Moreover, through the use of vibroacoustography at high frequencies (2.25 MHz and 1.75 MHz), Mehic et al. [56] were able to introduce low-frequency ultrasound $(500 \mathrm{kHz}$, like many studies quoted above) into a smaller volume of the brain than that amenable to typical low-frequency ultrasound transducers. Finally, Yu et al. (2016) [58] used sophisticated analysis of signals derived from dense EEG arrays to map the propagation of brain activity induced by transcranially delivered ultrasound, from its point of application to other portions of the brain.

Several groups have demonstrated successful UNMOD in larger animals - sheep and non-human primates (NHPs). For example, Lee et al. [59] applied transcranial focused ultrasound to sensorimotor and visual areas of the brains of sheep and measured EMG signals in the hind legs elicited by ultrasound application to the brain, as well as visually evoked potentials. Also, Tanter and colleagues [60] altered the saccade patterns of awake NHPs through use of transcranial delivery of focused ultrasound with a carrier frequency of $320 \mathrm{kHz}$ simultaneously with measurements of neural activity [61]. 
Table 5 Summaries of representative articles in section "Towards Modulating Brain Function with Ultrasound to Treat Pain"

\begin{tabular}{|c|c|c|c|}
\hline Article & Model & US parameters & Result/conclusion \\
\hline Kamimura et al 2016 [57] & $\begin{array}{l}\text { In vivo } \\
\text { Mice strain C57BL-6 }\end{array}$ & $\begin{array}{l}1.9 \mathrm{MHz} \\
\text { Pulse rep freq of } 1 \mathrm{kHz} \\
50 \% \text { duty cycle }(950 \text { pulses }) \\
\text { On } 1 \mathrm{~s} \text {, off } 1 \mathrm{~s} \text {, ten times }\end{array}$ & $\begin{array}{l}\text { Muscle movement at } 1.9 \mathrm{MHz} \\
\text { Pupil dilation at } 1.2 \mathrm{MPa} \\
\text { Pupil dilation at }>1.8 \mathrm{MPa}\end{array}$ \\
\hline Airan et al 2017 [66] & $\begin{array}{l}\text { In vivo } \\
\text { Fischer } 344 \text { rats }\end{array}$ & $\begin{array}{l}1 \mathrm{MHz} \\
0.5-\mathrm{Hz} \text { bursts for } 2 \mathrm{~min}\end{array}$ & Decrease in EEG at 1.0 and 1.5 MPA \\
\hline Tufail et al 2010 [48] & $\begin{array}{l}\text { In vivo } \\
\text { Anesthetized mice }\end{array}$ & $\begin{array}{l}\text { Pulses between } 80 \text { and } 225 \text { acoustic cycles } \\
\text { per pulse of } 0.16-0.57 \mathrm{~ms} \\
\text { Pulse repetition frequencies between } 1.2 \text { and } \\
3.0 \mathrm{kHzSpatial-peak} \mathrm{temporal-average} \\
\text { intensities }\left(I_{\text {SPTA }}\right) \text { of } 21-163 \mathrm{~mW} / \mathrm{cm}^{2}\end{array}$ & $\begin{array}{l}\text { Motor cortex activation; } \\
\text { Tail twitches and EMG activity in the } \\
\text { lumbo sacrocaudalis dorsalis } \\
\text { lateralis muscle; } \\
\text { EMG response in the contralateral } \\
\text { triceps brachii muscle }\end{array}$ \\
\hline King et al 2013 [49] & $\begin{array}{l}\text { In vivo } \\
\text { CBL-7 mice }\end{array}$ & $\begin{array}{l}500 \mathrm{kHz} \\
\text { Bandwidth of } 340 \text { to } 650 \mathrm{kHz} \\
\text { Ultrasound intensities from } 0.01 \text { to } \\
\quad 79.02 \mathrm{~W} / \mathrm{cm}^{2}(0.03 \text { to } 1.11 \mathrm{MPa}) \\
20 \text { to } 480 \mathrm{~ms}\end{array}$ & $\begin{array}{l}\text { Brain activation from ultrasound can } \\
\text { occur for ultrasound frequencies } \\
\text { between } 250 \text { and } 500 \mathrm{kHz} \text {. }\end{array}$ \\
\hline Mehic et al 2014 [56] & $\begin{array}{l}\text { In vivo } \\
\text { C57BL/6 mice }\end{array}$ & $\begin{array}{l}88 \text { bursts of } 500-\mathrm{kHz} \text { ultrasound } \\
\text { Length } 200 \mu \mathrm{s} \\
\text { Pulse repetition frequency of } 1.5 \mathrm{kHz} \text { in } \\
\quad \text { a } 1 \text {-s interval } I_{\mathrm{SPTA}}=5.25 \mathrm{~W} / \mathrm{cm}^{2}\end{array}$ & $\begin{array}{l}\text { Production of tail movement, unilateral } \\
\text { and bilateral movement of legs and } \\
\text { whiskers correlated with small } \mathrm{O}(1 \mathrm{~mm}) \\
\text { lateral movement of iFU focus. }\end{array}$ \\
\hline Tyler et al. 2008 [47] & $\begin{array}{l}\text { Hippocampus slice cultures } \\
\text { of mice brain }\end{array}$ & $\begin{array}{l}\text { Low-frequency US }(0.44-0.67 \mathrm{MHz}) \\
\text { Spatial-peak pulse-average } \\
\quad \text { intensity }\left(I_{\text {SPPA }}\right)=2.9 \mathrm{~W} / \mathrm{cm}^{2}\end{array}$ & Brain activation at $500 \mathrm{kHz}$ via EEG. \\
\hline
\end{tabular}

Finally, three intrepid groups [62-64] have applied neuromodulatory ultrasound in a transcranial fashion to the somatosensory cortex of healthy test subjects. The Tyler group [62] observed significant attenuation of the amplitudes of somatosensory evoked potentials elicited concurrently by median nerve stimulation. They also observed increased performance on sensory discrimination tasks without affecting task attention or response bias [63] as well as modulation of brain dynamics [64]. Yoo and colleagues [63] also stimulated the somatosensory cortex, thereby including tactile sensations in the hands of volunteers.

Three teams of researchers have applied UNMOD with therapeutic intent as of this writing. Min et al. (2011) [65] first induced acute epileptic seizures in a rat model. They then applied ultrasound, transcranially, to these anesthetized animals, with the following parameters: a carrier frequency of $690 \mathrm{KHz}$, with 500-ms-long pulses applied 100 times per second with an acoustic intensity of $130 \mathrm{~mW} / \mathrm{cm}^{2}$. EEG monitoring demonstrated reduced seizure activity as compared to untreated controls. In another approach to epilepsy treatment, Airan et al. [66] demonstrated the use of focused ultrasound to release neuromodulatory drugs from engineered nanoparticles that stopped chemically induced seizures in a rat model. After injection of the nanoparticles $\mathrm{IV}$, they applied iFU with a carrier frequency of $1 \mathrm{MHz}$, in short, repeating bursts at a frequency of $0.5 \mathrm{~Hz}$, for $2 \mathrm{~min}$, to the brains of these anesthetized mice. As in Min et al.
(2011) [65], they observed statistically significant decreases in total EEG power in mice experiencing seizures relative to control mice. Finally, and quite evocatively, Monti et al. (2016) [67] reported, in their letter to the editor, delivery of focused ultrasound to the thalamus of a patient who was in a comatose state for 19 days after TBI. The patient showed remarkable recovery from this state over a period of 3 days, with immediately observable clinical improvement. Their ultrasound had a $650-\mathrm{kHz}$ carrier frequency, an estimated in situ intensity of $0.72 \mathrm{~W} / \mathrm{cm}^{2}$, and pulse lengths of $0.5 \mathrm{~ms}$ delivered 100 times per second for $30 \mathrm{~s}$, with a $30 \mathrm{~s}$ pause, repeated ten times. This has some similarity to the results of Yoo et al. (2011) [68] who applied UNMOD to the thalamus of anesthetized rats, thereby reducing the time required for them to evince voluntary movement as they recovered from ketamine/xylazine anesthesia (Table 5).

\section{Summary and Conclusion}

Here we have reviewed a range of literature that highlights the potential for ultrasound to address painful conditions beyond its current clinical use for image-guiding injections.

We began by reviewing the literature relevant to the use of ultrasound to stimulate tactile touch. This work was pioneered by Gavrilov [1-4], starting in 1974 and 
continuing for more than a decade. The work by Dalecki's group [5] provided evidence to support Gavrilov's hypothesis that the tactile sensation arises due to tissue's exposure to the acoustic radiation force, the transfer of momentum from the sound field to tissue medium. We next reviewed research related to the use of ultrasound to diagnose tissue abnormalities, again as hypothesized by Gavrilov. These include identifying inflamed or neuropathic tissue in rodent models [7-9] and in humans [6, 12, 13].

In addition to this novel use of ultrasound for diagnostic purposes, more intense ultrasound can induce local anesthesia or analgesia affects. The nerve-blocking ability of ultrasound is associated with its ability to produce heat, as shown in Colucci et al. 2009 [15], in vivo. In humans, Hong et al. 1991 demonstrated temporary, ultrasound-induced reduction of peripheral nerve conduction.

A further increase in ultrasound intensity can ablate peripheral tissue, demonstrated to reduce bone pain associated with metastatic cancer. Hurwitz et al. 2014 [27] used MRI-guided HIFU to ablate the cancerous growths in a manner that reduced these patients' pain. Similar results were observed by Napoli et al. (2017) [29], Sharma et al. 2017 [32], and Yarmolenko PS et al. 2018 [31] for osteoid osteoma.

Pain can also be treated using focused ultrasound applied transcranially to the brain via ablative procedures [44, 45], a little studied but promising approach. Finally, transcranial ultrasound with significantly reduced intensity relative to ablative ultrasound can non-destructively and transiently activate as well as suppress brain function, shown in a range of animals (rodents [47-50, 52, 55-58, 65, 66, 68-70], rabbits [53], sheep [59], non-human primates $[60,61])$ and modulated brain function in people [62-64, 67]. Perhaps, 1 day, neuromodulatory ultrasound can ameliorate the patient's pain, at least temporarily.

In short, recent advances in ultrasound biophysics have opened up new opportunities to ameliorate the patient's pain, worthy of further study and trial.

\section{Compliance with Ethical Standards}

Conflict of Interest Michael S Bobola, Lucas Chen, Chikodi Ezeokeke Katy Kuznetsova, Annamarie C. Lahti, Alik Myroniv, Nels W. Schimek, Weicheng Lou, Madison L. Selby, and Pierre D. Mourad declare no conflict of interest.

Human and Animal Rights and Informed Consent This article does not contain any studies with human or animal subjects performed by any of the authors.

Open Access This article is distributed under the terms of the Creative Commons Attribution 4.0 International License (http:// creativecommons.org/licenses/by/4.0/), which permits unrestricted use, distribution, and reproduction in any medium, provided you give appropriate credit to the original author(s) and the source, provide a link to the Creative Commons license, and indicate if changes were made.

\section{References}

1. Gavrilov LR, Gersuni GV, Ilyinski OB, Tsirulnikov EM, Shchekanov EE. A study of reception with the use of focused ultrasound. I. Effects on the skin and deep receptor structures in man. Brain Res. 1977;135:265-77. https://doi.org/10.1016/00068993(77)91030-7.

2. Gavrilov LR, Gersuni GV, Ilyinsky OB, Tsirulnikov EM, Shchekanov EE. A study of reception with the use of focused ultrasound. II. Effects on the animal receptor structures. Brain Res. 1977;135:279-85. https://doi.org/10.1016/0006-8993(77) 91031-9.

3. Gavrilov LR. Use of focused ultrasound for stimulation of nerve structures. Ultrasonics. 1984;22(3):132-8. http://www.ncbi.nlm. nih.gov/pubmed/6372189. Accessed 24 Jan 2018

4. Gavrilov LRR, Tsirulnikov EMM, Davies IAIAI. Application of focused ultrasound for the stimulation of neural structures. Ultrasound Med Biol. 1996;22(2):179-92. https://doi.org/10. 1016/0301-5629(96)83782-3.

5. Dalecki D, Child SZ, Raeman CH, Carstensen EL. Tactile perception of ultrasound. J Acoust Soc Am. 1995;97(5):3165-70.

6. Dickey TC, Tych R, Kliot M, Loeser JD, Pederson K, Mourad PD. Intense focused ultrasound can reliably induce sensations in human test subjects in a manner correlated with the density of their mechanoreceptors. Ultrasound Med Biol. 2012;38(1):85-90. https://doi. org/10.1016/j.ultrasmedbio.2011.09.020.

7. Garcia JD, Gofeld M, Ray Illian P, Loeser JD, Kliot M, McClintic $\mathrm{AM}$, et al. Intense focused ultrasound as a potential research tool for the quantification of diurnal inflammatory pain. Ultrasonics. 2013;53(1):84-9. https://doi.org/10.1016/j.ultras.2012.04.002.

8. McClintic AM, Dickey TC, Gofeld M, et al. Rapid ultrasonic stimulation of inflamed tissue with diagnostic intent. J Acoust Soc Am. 2013;134(2):1521-9. https://doi.org/10.1121/1.4812872.

9. McClintic AM, Garcia JB, Gofeld M, et al. Intense focused ultrasound stimulation can safely stimulate inflamed subcutaneous tissue and assess allodynia. J Ther Ultrasound. 2014;2(1):8. https:// doi.org/10.1186/2050-5736-2-8.

10. Tych RE, Gofeld M, Jarvik JG, Kliot M, Loeser JD, McClintic AM, et al. Neuropathic tissue responds preferentially to stimulation by intense focused ultrasound. Ultrasound Med Biol. 2013;39(1):1116. https://doi.org/10.1016/j.ultrasmedbio.2012.08.012.

11. McClintic AM, Dickey TCTTC, Gofeld M, et al. Intense focused ultrasound preferentially stimulates subcutaneous and focal neuropathic tissue: preliminary results. Pain Med. 2013;14(1):84-92. https://doi.org/10.1111/j.1526-4637.2012.01510.x.

12. Gellhorn AC, Gillenwater C, Mourad PD. Intense focused ultrasound stimulation of the rotator cuff: evaluation of the source of pain in rotator cuff tears and tendinopathy. Ultrasound Med Biol. 2015;41(9):2412-9. https://doi.org/10.1016/j.ultrasmedbio.2015. 05.005 .

13. Mourad PD, Friedly JL, McClintic AM, Olmstead TA, Loeser JD. Intense focused ultrasound preferentially stimulates transected nerves within residual limbs: pilot study. Pain Med. 2017;19:5419. https://doi.org/10.1093/pm/pnx188.

14. Wright a, Graven-Nielsen T, Davies I, Arendt-Nielsen L. Temporal summation of pain from skin, muscle and joint following nociceptive ultrasonic stimulation in humans. Exp Brain Res. 2002;144: 475-82. https://doi.org/10.1007/s00221-002-1062-4.

15. Colucci V, Strichartz G, Jolesz F, Vykhodtseva N, Hynynen K. Focused ultrasound effects on nerve action potential in vitro. Ultrasound Med Biol. 2009;35(10):1737-47. https://doi.org/10. 1016/j.ultrasmedbio.2009.05.002.

16. Hong CZ. Reversible nerve conduction block in patients with polyneuropathy after ultrasound thermotherapy at therapeutic 
dosage. Arch Phys Med Rehabil. 1991;72(2):132-7. http://www. ncbi.nlm.nih.gov/pubmed/1846738. Accessed 25 Jan 2018

17. Foley JL, Little JW, Vaezy S. Image-guided high-intensity focused ultrasound for conduction block of peripheral nerves. Ann Biomed Eng. 2006;35(1):109-19. https://doi.org/10.1007/s10439-0069162-0.

18. Zhou Z, Wu S, Wang C-Y, Ma H-Y, Lin C-C, Tsui P-H. Monitoring radiofrequency ablation using real-time ultrasound Nakagami imaging combined with frequency and temporal compounding techniques. Talkachova A, ed. PLoS One. 2015;10(2):e0118030. https://doi.org/10.1371/journal.pone.0118030.

19. Jolesz FA, Hynynen KH. MR-guided focused ultrasound surgery. J Comput Assist Tomogr. 1992;16(6):956-65.

20. Hynynen K, Damianou C, Darkazanli A, Unger E, Schenck JF. The feasibility of using MRI to monitor and guide noninvasive ultrasound surgery. Ultrasound Med Biol. 1993;19(1):91-2. http://www. ncbi.nlm.nih.gov/pubmed/8456533. Accessed 29 Jan 2018

21. Zhang L, Zhang W, Orsi F, Chen W, Wang Z. Ultrasound-guided high intensity focused ultrasound for the treatment of gynaecological diseases: a review of safety and efficacy. Int $\mathrm{J}$ Hyperth. 2015;31(3):280-4. https://doi.org/10.3109/02656736. 2014.996790.

22. Jolesz FA, McDannold NJ. Magnetic resonance-guided focused ultrasound: a new technology for clinical neurosciences. Neurol Clin. 2014;32(1):253-69. https://doi.org/10.1016/j.ncl.2013.07.008.

23. Jeong J-H, Hong GP, Kim Y-R, Ha J-E, Lee K-S. Clinical consideration of treatment to ablate uterine fibroids with magnetic resonance imaging-guided high intensity focused ultrasound (MRgFUS): Sonalleve. J Menopausal Med. 2016;22(2):94-107. https://doi.org/10.6118/jmm.2016.22.2.94.

24. Chin JL, Billia M, Relle J, Roethke MC, Popeneciu IV, Kuru TH, et al. Magnetic resonance imaging-guided transurethral ultrasound ablation of prostate tissue in patients with localized prostate cancer: a prospective phase 1 clinical trial. Eur Urol. 2016;70(3):447-55. https://doi.org/10.1016/j.eururo.2015.12.029.

25. Huisman M, ter Haar G, Napoli A, Hananel A, Ghanouni P, Lövey $\mathrm{G}$, et al. International consensus on use of focused ultrasound for painful bone metastases: current status and future directions. Int $\mathrm{J}$ Hyperth. 2015;31(3):251-9. https://doi.org/10.3109/02656736. 2014.995237.

26. Ringe KI, Panzica M, von Falck C. Thermoablation of bone tumors. Rofo. 2016;188(6):539-50. https://doi.org/10.1055/s-0042100477.

27. Hurwitz MD, Ghanouni P, Kanaev SV, Iozeffi D, Gianfelice D, Fennessy FM, et al. Magnetic resonance-guided focused ultrasound for patients with painful bone metastases: phase III trial results. JNCI J Natl Cancer Inst. 2014;106(5) https://doi.org/10.1093/ jnci/dju082.

28. Langley GB, Sheppeard H. The visual analogue scale: its use in pain measurement. Rheumatol Int. 1985;5(4):145-8. http://www. ncbi.nlm.nih.gov/pubmed/4048757. Accessed 27 Feb 2018

29. Napoli A, Bazzocchi A, Scipione R, Anzidei M, Saba L, Ghanouni $\mathrm{P}$, et al. Noninvasive therapy for osteoid osteoma: a prospective developmental study with MR imaging-guided high-intensity focused ultrasound. Radiology. 2017;285(1):186-96. https://doi.org/ 10.1148/radiol.2017162680.

30. Li C, Zhang W, Fan W, Huang J, Zhang F, Wu P. Noninvasive treatment of malignant bone tumors using high-intensity focused ultrasound. Cancer. 2010;116(16):3934-42. https://doi.org/10. 1002/cncr.25192.

31. Yarmolenko PS, Eranki A, Partanen A, Celik H, Kim AR, Oetgen $\mathrm{M}$, et al. Technical aspects of osteoid osteoma ablation in children using MR-guided high intensity focussed ultrasound. Int J Hyperth. 2018;34(1):49-58. https://doi.org/10.1080/02656736.2017. 1315458
32. Sharma K V., Yarmolenko PS, Celik H, et al. Comparison of noninvasive high-intensity focused ultrasound with radiofrequency ablation of osteoid osteoma. 2017;190:222-228.e1. http://www. sciencedirect.com/science/article/pii/S002234761730896X?via\% 3Dihub. Accessed 17 Jan 2018.

33. Liberman B, Gianfelice D, Inbar Y, Beck A, Rabin T, Shabshin N, et al. Pain palliation in patients with bone metastases using MR-guided focused ultrasound surgery: a multicenter study. Ann Surg Oncol. 2009;16(1):140-6. https://doi.org/10.1245/s10434-008-0011-2.

34. Weeks EM, Platt MW, Gedroyc W. MRI-guided focused ultrasound (MRgFUS) to treat facet joint osteoarthritis low back pain - case series of an innovative new technique. Eur Radiol. 2012;22(12): 2822-35. https://doi.org/10.1007/s00330-012-2628-6.

35. Rodrigues DB, Stauffer PR, Vrba D, Hurwitz MD. Focused ultrasound for treatment of bone tumours. Int J Hyperth. 2015;31(3): 260-71. https://doi.org/10.3109/02656736.2015.1006690.

36. Pinton G, Aubry J-F, Bossy E, Muller M, Pernot M, Tanter M. Attenuation, scattering, and absorption of ultrasound in the skull bone. Med Phys. 2011;39(1):299-307. https://doi.org/10.1118/1. 3668316.

37. Sun J, Hynynen K. The potential of transskull ultrasound therapy and surgery using the maximum available skull surface area. $\mathrm{J}$ Acoust Soc Am. 1999;105(120):2519-1705. https://doi.org/10. 1121/1.2354073.

38. Monteith S, Snell J, Eames M, Kassell NF, Kelly E, Gwinn R. Transcranial magnetic resonance-guided focused ultrasound for temporal lobe epilepsy: a laboratory feasibility study. J Neurosurg. 2016;125(6):1557-64. https://doi.org/10.3171/2015. 10.JNS1542.

39. Chang WS, Jung HH, Kweon EJ, Zadicario E, Rachmilevitch I, Chang JW. Unilateral magnetic resonance guided focused ultrasound thalamotomy for essential tremor: practices and clinicoradiological outcomes. J Neurol Neurosurg Psychiatry. 2015;86:257-64. https://doi.org/10.1136/jnnp-2014-307642.

40. Fahn, S \& Tolosa, Eduard \& Marin C. Parkinson's Disease and Movement Disorders.: Clinical Rating Scale for Tremor. 2nd ed. (Joseph Jankovic ET, ed.). Urban \& Schwarzenberg; 1988. https:// www.researchgate.net/profile/Eduard Tolosa/publication/ 307538277_Clinical_Rating_Scale_for_Tremor/links/ 5832e79508ae004f74c57 ae1/Clinical-Rating-Scale-for-Tremor. pdf. Accessed 28 Feb 2018.

41. Magara A, Bühler R, Moser D, Kowalski M, Pourtehrani P, Jeanmonod D. First experience with MR-guided focused ultrasound in the treatment of Parkinson's disease. J Ther Ultrasound. 2014;2(1):11. https://doi.org/10.1186/2050-5736-2-11.

42. Perlmutter JS. Assessment of Parkinson disease manifestations. Curr Protoc Neurosci 2009;Chapter 10:Unit10.1. https://doi.org/ 10.1002/0471142301.ns1001s49

43. Chazen JL, Sarva H, Stieg PE, Min RJ, Ballon DJ, Pryor KO, et al. Clinical improvement associated with targeted interruption of the cerebellothalamic tract following MR-guided focused ultrasound for essential tremor. J Neurosurg October. 2017:1-9. https://doi. org/10.3171/2017.4.JNS162803.

44. Martin E, Jeanmonod D, Morel A, Zadicario E, Werner B. Highintensity focused ultrasound for noninvasive functional neurosurgery. Ann Neurol. 2009;66(6):858-61. https://doi.org/10.1002/ana. 21801.

45. Jeanmonod D, Werner B, Morel A, Michels L, Zadicario E, Schiff $\mathrm{G}$, et al. Transcranial magnetic resonance imaging-guided focused ultrasound: noninvasive central lateral thalamotomy for chronic neuropathic pain. Neurosurg Focus. 2012;32:E1. https://doi.org/ 10.3171/2011.10.FOCUS11248.

46. Fry WJ, Fry FJ, Barnard JW, Krumins RF, Brennan JF. Ultrasonic lesions in the mammalian central nervous system. Science (80- ). 1955;122(3168) http://science.sciencemag.org/content/122/3168/ 517.long. Accessed 24 May 2017 
47. Tyler WJ, Tufail Y, Finsterwald M, Tauchmann ML, Olson EJ, Majestic C. Remote excitation of neuronal circuits using low- intensity, low-frequency ultrasound. PLoS One. 2008;3(10):e3511. https://doi.org/10.1186/1471-2202-12-23.

48. Tufail Y, Matyushov A, Baldwin N, Tauchmann ML, Georges J, Yoshihiro A, et al. Transcranial pulsed ultrasound stimulates intact brain circuits. Neuron. 2010;66(5):681-94. https://doi.org/10.1016/ j.neuron.2010.05.008.

49. King RL, Brown JR, Newsome WT, Pauly KB. Effective parameters for ultrasound-induced in vivo neurostimulation. Ultrasound Med Biol. 2013;39(2):312-31. https://doi.org/10.1016/j. ultrasmedbio.2012.09.009.

50. Ye PP, Brown JR, Pauly KB. Frequency dependence of ultrasound neurostimulation in the mouse brain. Ultrasound Med Biol. 2016;42(7):1512-30. https://doi.org/10.1016/j.ultrasmedbio.2016. 02.012 .

51. Younan Y, Deffieux T, Larrat B, et al. Influence of the pressure field distribution in transcranial ultrasonic neurostimulation. Med Phys. 2013;40:82902. https://doi.org/10.1118/1.4812423.

52. Moore ME, Loft JM, Clegern WC, Wisor JP. Manipulating neuronal activity in the mouse brain with ultrasound: a comparison with optogenetic activation of the cerebral cortex. Neurosci Lett. 2015;604:183-7. https://doi.org/10.1016/j.neulet.2015.07.024.

53. Yoo S-SS, Bystritsky A, Lee J-HH, Zhang Y, Fischer K, Min BK, et al. Focused ultrasound modulates region-specific brain activity. NeuroImage. 2011;56(3):1267-75. https://doi.org/10.1016/j. neuroimage.2011.02.058.

54. Kim H, Taghados SJ, Fischer K, Maeng L-S, Park S, Yoo S-S. Noninvasive transcranial stimulation of rat abducens nerve by focused ultrasound. Ultrasound Med Biol. 2012;38(9):1568-75. https://doi.org/10.1016/j.ultrasmedbio.2012.04.023.

55. Kim H, Chiu A, Lee SD, Fischer K, Yoo S-S. Focused ultrasoundmediated non-invasive brain stimulation: examination of sonication parameters. Brain Stimul. 2014;7(5):748-56. https://doi.org/10. 1016/j.brs.2014.06.011.

56. Mehić E, Xu JM, Caler CJ, Coulson NK, Moritz CT, Mourad PD. Increased anatomical specificity of neuromodulation via modulated focused ultrasound. PLoS One. 2014;9(2):e86939. https://doi.org/ 10.1371/journal.pone.0086939.

57. Kamimura HAS, Wang S, Chen H, Wang Q, Aurup C, Acosta C, et al. Focused ultrasound neuromodulation of cortical and subcortical brain structures using 1.9 MHz. Med Phys. 2016;43(10):5730-5. https://doi.org/10.1118/1.4963208.

58. Yu K, Sohrabpour A, He B. Electrophysiological source imaging of brain networks perturbed by low-intensity transcranial focused ultrasound. IEEE Trans Biomed Eng. 2016;63(9):1787-94. https:// doi.org/10.1109/TBME.2016.2591924.

59. Lee W, Lee SD, Park MY, Foley L, Purcell-Estabrook E, Kim H, et al. Image-guided focused ultrasound-mediated regional brain stimulation in sheep. Ultrasound Med Biol. 2016;42(2):459-70. https://doi.org/10.1016/j.ultrasmedbio.2015.10.001.

60. Deffieux T, Younan Y, Wattiez N, Tanter M, Pouget P, Aubry JF. Low-intensity focused ultrasound modulates monkey visuomotor behavior. Curr Biol. 2013;23(23):2430-3. https://doi.org/10.1016/ j.cub.2013.10.029.

61. Wattiez N, Constans C, Deffieux T, Daye PM, Tanter M, Aubry JF, et al. Transcranial ultrasonic stimulation modulates single-neuron discharge in macaques performing an antisaccade task. Brain Stimul. 2017;10(6):1024-31. https://doi.org/10.1016/j.brs.2017. 07.007 .

62. Legon W, Sato T, Opitz A, et al. Transcranial focused ultrasound modulates the activity of primary somatosensory cortex in humans. Nat Neurosci. 2014;17(2):322-9. https://doi.org/10.1227/NEU. 0000000000000365.

63. Lee W, Kim H, Jung Y, Song I, Chung YA, Yoo S. Image-guided transcranial focused ultrasound stimulates human primary somatosensory cortex. Scientific Reports. 2015;5:1-10. https://doi.org/10. 1038/srep08743

64. Mueller J, Legon W, Opitz A, Sato TF, Tyler WJ. Transcranial focused ultrasound modulates intrinsic and evoked EEG dynamics. Brain Stimul. 2014;7(6):900-8. https://doi.org/10.1016/j.brs.2014. 08.008.

65. Min B-K, Bystritsky A, Jung K-I, Fischer K, Zhang Y, Maeng LS, et al. Focused ultrasound-mediated suppression of chemicallyinduced acute epileptic EEG activity. BMC Neurosci. 2011;12(1): 23. https://doi.org/10.1186/1471-2202-12-23.

66. Airan RD, Meyer RA, Ellens NPK, Rhodes KR, Farahani K, Pomper MG, et al. Noninvasive targeted transcranial neuromodulation via focused ultrasound gated drug release from nanoemulsions. Nano Lett. 2017;17(2):652-9. https://doi.org/10. 1021/acs.nanolett.6b03517.

67. Monti MM, Schnakers C, Korb AS, Bystritsky A, Vespa PM. Noninvasive ultrasonic thalamic stimulation in disorders of consciousness after severe brain injury: a first-in-man report. Brain Stimul. 2016;9(6):940-1. https://doi.org/10.1016/j.brs.2016.07.008.

68. Yoo S-S, Kim H, Min B-K, Franck E, Park S. Transcranial focused ultrasound to the thalamus alters anesthesia time in rats. Neuroreport. 2011;22(15):783-7. https://doi.org/10.1097/WNR. 0b013e32834b2957.

69. Younan Y, Deffieux T, Larrat B, Fink M, Tanter M, Aubry J-F. Influence of the pressure field distribution in transcranial ultrasonic neurostimulation. Med Phys. 2013;40:082902. https://doi.org/10. 1118/1.4812423.

70. Kim S, Hamilton R, Pineles S, Bergsneider M, Hu X. Noninvasive intracranial hypertension detection utilizing semisupervised learning. IEEE Trans Biomed Eng. 2013;60(4):1126-33. https://doi.org/ 10.1109/TBME.2012.2227477. 